\title{
PENENTUAN KRITERIA DESAIN PENGEMBANGAN OBJEK WISATA WADUK SEMPOR DENGAN METODE PARTISIPATORI ERGONOMI
}

\author{
${ }^{1}$ Ahmad Yakub Katibi, ${ }^{2}$ Widyastuti \\ 1,2Program Studi Teknik Industri Sekolah Tinggi Teknologi Muhammadiyah Kebumen, \\ Jalan Indrakila no. 38A Kebumen \\ e-mail: yaqub705@gmail.com
}

\begin{abstract}
Abstrak
Waduk Sempor adalah objek wisata yang juga dimanfaatkan sebagai sumber mata pencaharian bagi sebagian warga sekitarnya. Saat ini terjadi penurunan jumlah pengunjung yang disebabkan rusaknya beberapa fasilitas penunjang dan persaingan dengan objek wisata lain. Dalam upaya peningkatan daya saing diperlukan pengembangan objek wisata. Berdasarkan hal tersebut maka dalam penelitian ini dilakukan penentuan kriteria desain pengembangan Waduk Sempor. Penentuan kriteria desain dilakukan dengan pendekatan metode Partisipatori Ergonomi, penentukan korelasi dan prioritas kriteria dianilisis menggunakan Partial Least Square (PLS). Hasil strukturisasi kriteria desain pengembangan Waduk Sempor berdasarkan tingkat signifikansi pengaruh dari nilai tertinggi hingga terendah terdiri dari: daya tarik, akomodasi, fasilitas dan pelayanan wisata, kebersihan, aksesibilitas, keamanan dan keselamatan keamanan, infrastruktur lain.
\end{abstract}

Kata kunci : Waduk Sempor; kriteria desain; partisiaptori ergonomi; Partial Least Square (PLS)

\section{PENDAHULUAN}

Waduk Sempor adalah salah satu objek wisata yang terletak di Kecamatan Sempor Kabupaten Kebumen. Waduk ini dimanfaatkan sebagai tempat wisata dan sumber mata pencaharian bagi sebagian warga sekitarnya. Pada sepuluh tahun terakhir terjadi penurunan jumlah pengunjung yang disebabkan rusaknya beberapa fasilitas penunjang dan persaingan dengan objek wisata lain. Untuk itu diperlukan upaya peningkatkan daya saing dengan melakukan pengembangan di objek wisata Waduk Sempor (Pengelola Waduk Sempor, 2016).

Dalam pengembangan sebuah objek wisata diperlukan suatu kriteria desain pengembangan sesuai kebutuhan seluruh pemangku kepentingan (Huwaniar dan Suprihardjo, 2013). Penentuan kriteria menggunakan metode pendekatan partisipatori ergonomi diharapkan sesuai dengan keinginan pemangku kepentingan. Hal tersebut diperlukan dalam peningkatan daya saing dan fasilitas penunjang. Berdasarkan latar belakang tersebut, maka penelitian ini bertujuan untuk menentukan kriteria pengembangan dengan pendekatan partisipatori ergonomi.

\section{METODE PENELITIAN}

\section{A. Partisipatori Ergonomi}

Dalam penelitian ini partisipatori ergonomi diterapkan dalam menentukan kriteria desain pengembangan Waduk Sempor yang diawali dengan studi literatur. Langkah selanjutnya adalah penentuan tim partisipatori ergonomi yang terdiri dari pengunjung, pengelola, stakeholder dan ahli pariwisata. Tahap berikutnya yaitu mengidentifikasi kriteria (variabel laten dan konstruk) pengembangan Waduk Sempor menggunakan metode Focus Group Discussion (FGD) yang diawali dengan penjelasan ilmu ergonomi, serta tujuan penelitian. Peserta FGD yaitu tim partisipatori yang berjumlah delapan orang (pengunjung 2 orang, stakeholder 2 orang, pengelola 3 orang, ahli wisata perwakilan Dinas Pariwisata Kebumen 1 orang). Penilaian kriteria hasil FGD dilakukan dengan menyebarkan kuesioner kepada tim ergonomi partisipatif. Tahap terakhir yaitu penentuan prioritas pengembangan menggunakan metode Partial Least Square (PLS) dan uji model yang digunakan dalam rekomendasi. 


\section{B. Survei}

Survei pada penelitian ini digunakan untuk penilaian kriteria hasil FGD dengan responden tim partisipatori ergonomi yang berjumlah 96 orang. Responden terdiri 8 orang tim FGD dan 88 orang pengunjung yang ditentukan menggunakan metode accidental sampling. Skala penilaian menggunakan skala likert tersaji pada Tabel 1 sebagai berikut:

\begin{tabular}{lc}
\multicolumn{2}{c}{ Tabel 1. Skala penilaian } \\
\hline \multicolumn{1}{c}{ Spesifikasi } & Nilai \\
\hline Sangat berpengaruh & 5 \\
Berpengaruh & 4 \\
Cukup berpengaruh & 3 \\
Tidak berpengaruh & 2 \\
Sangat tidak berpengaruh & 1 \\
\hline
\end{tabular}

\section{Analisis Data}

Data hasil survei dianalisis menggunakan metode Partial Least Square (PLS) dengan software SmartPLS 3.2.4. Analisis ini bertujuan untuk menentukan korelasi dan prioritas kriteria desain pengembangan dengan tahapan sebagai berikut:

1. Analisis Outer Model

a. Convergent validity yaitu penentuan hubungan variabel laten dengan indikatorindikatornya. Variabel dinyatakan valid jika nilai konstruk yang diukur lebih besar dari 0,5 (Hartomo, Setiawan, dan Kurniawan, 2014).

b. Variabel dinyatakan memenuhi Discriminant Validity apabila nilai konstruk yang dituju lebih besar dibandingkan nilai konstruk yang lain dan nilai AVE harus di atas 0,5 (Hartomo, Setiawan, dan Kurniawan, 2014).

c. Variabel dinyatakan lulus Uji Reliabilitas jika nilai cronbach's alpha lebih besar dari 0,6 , hal ini menunjukkan variabel memiliki reliabilitas atau keandalan tinggi sebagai alat ukur (Priyono dan Sunaryo, 2013).

2. Analisis Inner Model

Analisis inner dimaksudkan untuk melihat hubungan antar konstruk, nilai signifikansi dan nilai $R$-square. Semakin besar nilai $R$-square maka semakin besar pula pengaruh variabel independent terhadap variabel dependent sehingga semakin baik nilai $R$-Square maka semakin baik persamaan strukturalnya. Pengujian hipotesis dilihat dari nilai original sample yang menandakan hubungan antara kriteria dengan kriteria desain pengembangan dan nilai T-statistik yang menjelaskan signifikansi pengaruh kriteria terhadap kriteria desain pengembangan objek wisata Waduk Sempor.

Hipotesis pada penelitian ini terdiri dari:

H1: Daya tarik berpengaruh signifikan dan positif terhadap kriteria desain

$\mathrm{H} 2$ : Akomodasi berpengaruh signifikan dan positif terhadap kriteria desain

H3: Fasilitas dan pelayanan wisata berpengaruh signifikan dan positif terhadap kriteria desain

H4: Aksesibilitas berpengaruh signifikan dan positif terhadap kriteria desain

H5: Kebersihan berpengaruh signifikan dan positif terhadap kriteria desain

H6: Keamanan dan Keselamatan berpengaruh signifikan dan positif terhadap kriteria desain

H7: Instruktur Lain berpengaruh signifikan dan positif terhadap kriteria desain 


\section{HASIL DAN PEMBAHASAN}

\section{A. Hasil FGD}

Penentuan kriteria dengan metode FGD yang melibatkan tim partisipatori ergonomi memperoleh hasil seperti pada Tabel 2.

Tabel 2. Data hasil FGD

\begin{tabular}{|c|c|}
\hline Kriteria & Sub Kriteria \\
\hline Daya Tarik & $\begin{array}{l}\text { Wahana main anak, spot foto, atraksi budaya lokal } \\
\text { (pagelaran budaya), kebun binatang mini, tour perahu } \\
\text { wisata, festival, sunmor (pasar minggu pagi) sempor. }\end{array}$ \\
\hline Akomodasi & Homestay \\
\hline $\begin{array}{l}\text { Fasilitas dan } \\
\text { Pelayanan Wisata }\end{array}$ & $\begin{array}{l}\text { Musholla, merchandise shop, kantor informasi wisata, } \\
\text { galeri waduk sempor. Fasilitas pelayanan kesehatan, } \\
\text { fasilitas keamanan, papan informasi, papan penunjuk arah, } \\
\text { gazebo. }\end{array}$ \\
\hline $\begin{array}{l}\text { Aksesibilitas } \\
\text { Kebersihan }\end{array}$ & $\begin{array}{l}\text { Pencahayaan jalan, area parkir yang luas } \\
\text { Papan perintah membuang sampah pada tempatnya, toilet. }\end{array}$ \\
\hline $\begin{array}{l}\text { Keamanan } \\
\text { Keselamatan }\end{array}$ & $\begin{array}{l}\text { Keamanan area parkir, penjelasan tentang keselamatan, } \\
\text { papan peringatan. }\end{array}$ \\
\hline Infrastruktur Lain & Wastafel umum. \\
\hline
\end{tabular}

\section{B. Analisis Data}

1. Model pengukuran (Outer Model)

Model struktural dalam penelitian ini ditampilkan pada Gambar 1 yang menjelaskan bahwa terdapat 8 (delapan) konstruk kriteria pengembangan yang terdiri dari 26 indikator yaitu: daya tarik (x1: wahana anak, $\mathrm{x} 2$ : spot foto, $\mathrm{x} 3$ : atraksi budaya lokal, $\mathrm{x} 4$ : kebun binatang mini, $\mathrm{x} 5$ : tour perahu wisata, $\mathrm{x} 6$ : festival, $\mathrm{x} 7$ : sunmor (pasar minggu pagi) sempor; akomodasi (x8: homestay); fasilitas dan pelayanan wisata(x9: musholla, $\mathrm{x} 10$ : merchandise shop, $\mathrm{x} 11$ :kantor informasi wisata, $x 12$ : galeri waduk sempor, $\mathrm{x} 13$ : fasilitas pelayanan kesehatan, $\mathrm{x} 14$ : fasilitas keamanan, x15: papan informasi, x16: papan penunjuk arah x17: gazebo); aksesibilitas (x18: pencahayaan jalan, x19: area parkir yang luas); kebersihan (x20: papan perintah membuang sampah pada tempatnya, x21: toilet); keamanan dan keselamatan (x22: keamanan area parkir, $\mathrm{x} 24$ : papan peringatan, $\mathrm{x} 23$ : penjelasan tentang keselamatan); infrastruktur lain (x25: wastafel umum); keseluruhan kriteria (x26: keseluruhan kriteria). 


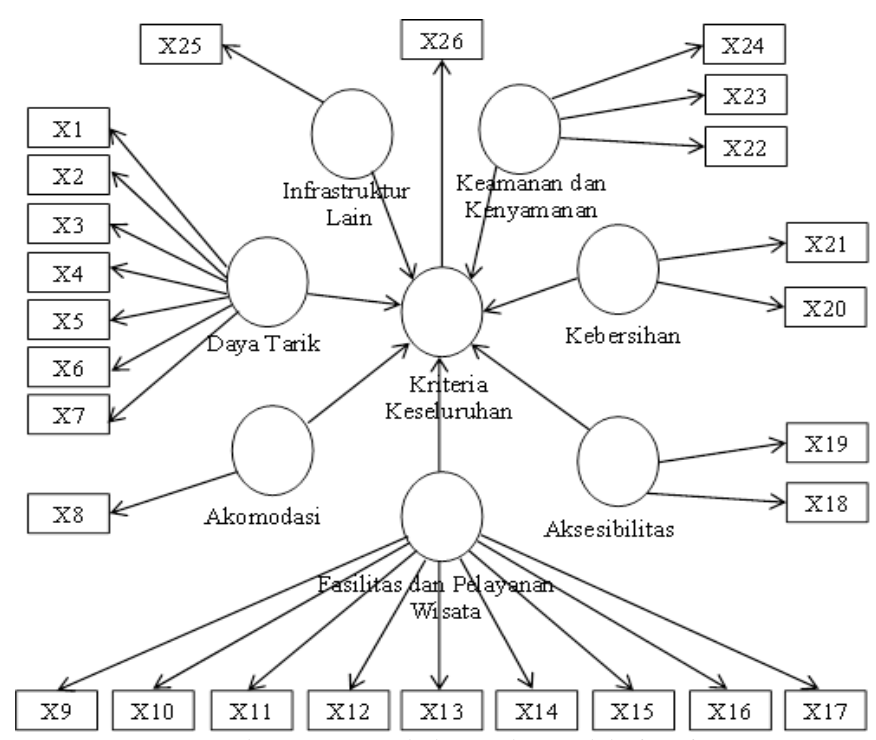

Gambar. 1 Model struktural kriteria

a. Convergent validity

Hasil nilai uji convergent validity tersaji pada Tabel 3.

Tabel 3. Convergent validity

\begin{tabular}{|c|c|c|c|c|c|c|c|c|}
\hline & $\begin{array}{l}\text { Daya } \\
\text { Tarik }\end{array}$ & $\begin{array}{c}\text { Ako- } \\
\text { modasi }\end{array}$ & $\begin{array}{c}\text { Fasilitas } \\
\text { dan } \\
\text { Pelayanan } \\
\text { Wisata } \\
\end{array}$ & $\begin{array}{c}\text { Aksesi- } \\
\text { bilitas }\end{array}$ & $\begin{array}{l}\text { Keber- } \\
\text { sihan }\end{array}$ & $\begin{array}{c}\text { Keamanan } \\
\text { dan } \\
\text { Kenyamanan }\end{array}$ & $\begin{array}{l}\text { Infra } \\
\text { struktur } \\
\text { Lain }\end{array}$ & $\begin{array}{c}\text { Kriteria } \\
\text { Keselu- } \\
\text { ruhan }\end{array}$ \\
\hline $\mathrm{X} 1$ & 0,713 & & & & & & & \\
\hline X2 & 0,663 & & & & & & & \\
\hline X3 & 0,809 & & & & & & & \\
\hline X4 & 0,557 & & & & & & & \\
\hline X5 & 0,482 & & & & & & & \\
\hline X6 & 0,602 & & & & & & & \\
\hline X7 & 0,530 & & & & & & & \\
\hline X8 & & 1,000 & & & & & & \\
\hline X9 & & & 0,769 & & & & & \\
\hline X10 & & & 0,790 & & & & & \\
\hline X11 & & & 0,625 & & & & & \\
\hline $\mathrm{X} 12$ & & & 0,716 & & & & & \\
\hline X13 & & & 0,728 & & & & & \\
\hline X14 & & & 0,510 & & & & & \\
\hline X15 & & & 0,762 & & & & & \\
\hline X16 & & & 0,755 & & & & & \\
\hline $\mathrm{X} 17$ & & & 0,608 & & & & & \\
\hline X18 & & & & 0,865 & & & & \\
\hline X19 & & & & 0,907 & & & & \\
\hline X20 & & & & & 0,918 & & & \\
\hline $\mathrm{X} 21$ & & & & & 0,902 & & & \\
\hline X22 & & & & & & 0,810 & & \\
\hline X23 & & & & & & 0,867 & & \\
\hline X24 & & & & & & 0,877 & & \\
\hline X25 & & & & & & & 1,000 & \\
\hline $\mathrm{X} 26$ & & & & & & & & 1,000 \\
\hline
\end{tabular}


Berdasarkan hasil tersebut indikator x 5 dinyatakan tidak valid karena nilai loading factor lebih kecil dari 0,5 sedangkan untuk indikator lain dinyatakan valid (loading factor lebih besar dari 0,5).

b. Discriminant Validity

Hasil nilai uji convergent validity tersaji pada Tabel 4.

Tabel 4. Cross loading

\begin{tabular}{|c|c|c|c|c|c|c|c|c|}
\hline & $\begin{array}{l}\text { Daya } \\
\text { Tarik }\end{array}$ & $\begin{array}{c}\text { Ako } \\
\text { modasi }\end{array}$ & $\begin{array}{c}\text { Fasilitas } \\
\text { dan } \\
\text { Pelayanan } \\
\text { Wisata }\end{array}$ & $\begin{array}{l}\text { Aksesi } \\
\text { bilitas }\end{array}$ & $\begin{array}{l}\text { Keber- } \\
\text { sihan }\end{array}$ & $\begin{array}{c}\text { Keamanan } \\
\text { dan } \\
\text { Kenyamanan }\end{array}$ & $\begin{array}{l}\text { Infra } \\
\text { struktur } \\
\text { Lain }\end{array}$ & $\begin{array}{c}\text { Kriteria } \\
\text { Keselu } \\
\text { Ruhan }\end{array}$ \\
\hline $\mathrm{X} 1$ & 0,713 & 0,116 & 0,570 & 0,463 & 0,302 & 0,365 & 0,074 & 0,607 \\
\hline $\mathrm{X} 2$ & 0,663 & 0,066 & 0,513 & 0,392 & 0,231 & 0,390 & 0,070 & 0,482 \\
\hline X3 & 0,809 & 0,168 & 0,447 & 0,435 & 0,349 & 0,413 & 0,109 & 0,611 \\
\hline $\mathrm{X} 4$ & $0,557 *$ & 0,168 & 0,223 & 0,109 & 0,112 & 0,142 & 0,212 & 0,293 \\
\hline X5 & $0,482 *$ & 0,163 & 0,392 & 0,222 & 0,269 & 0,296 & 0,225 & 0,360 \\
\hline X6 & 0,602 & 0,317 & 0,330 & 0,239 & 0,134 & 0,201 & 0,127 & 0,299 \\
\hline X7 & $0,530^{*}$ & 0,176 & 0,294 & 0,224 & 0,171 & 0,153 & $-0,144$ & 0,318 \\
\hline X8 & 0,240 & 1,000 & 0,241 & 0,102 & 0,190 & 0,193 & $-0,050$ & 0,197 \\
\hline X9 & 0,420 & 0,135 & 0,769 & 0,463 & 0,488 & 0,537 & 0,113 & 0,589 \\
\hline X10 & 0,448 & 0,119 & 0,790 & 0,615 & 0,504 & 0,545 & 0,106 & 0,630 \\
\hline X11 & 0,288 & 0,165 & $0,625^{*}$ & 0,411 & 0,327 & 0,473 & 0,018 & 0,345 \\
\hline $\mathrm{X} 12$ & 0,487 & 0,125 & 0,716 & 0,413 & 0,375 & 0,462 & 0,154 & 0,508 \\
\hline X13 & 0,491 & 0,212 & 0,728 & 0,449 & 0,618 & 0,602 & 0,124 & 0,601 \\
\hline X14 & 0,321 & 0,461 & $0,510^{*}$ & 0,359 & 0,283 & 0,352 & $-0,033$ & 0,392 \\
\hline X15 & 0,577 & 0,226 & 0,762 & 0,579 & 0,446 & 0,615 & 0,234 & 0,641 \\
\hline X16 & 0,549 & 0,127 & 0,755 & 0,615 & 0,530 & 0,539 & 0,174 & 0,673 \\
\hline X17 & 0,466 & 0,045 & $0,608^{*}$ & 0,387 & 0,358 & 0,354 & 0,035 & 0,514 \\
\hline X18 & 0,453 & 0,155 & 0,576 & 0,865 & 0,557 & 0,495 & 0,114 & 0,570 \\
\hline X19 & 0,457 & 0,036 & 0,647 & 0,907 & 0,619 & 0,710 & 0,211 & 0,680 \\
\hline X20 & 0,388 & 0,175 & 0,611 & 0,591 & 0,918 & 0,672 & 0,282 & 0,622 \\
\hline X21 & 0,299 & 0,171 & 0,547 & 0,621 & 0,902 & 0,697 & 0,119 & 0,572 \\
\hline X22 & 0,347 & 0,024 & 0,627 & 0,645 & 0,616 & 0,810 & 0,097 & 0,622 \\
\hline X23 & 0,406 & 0,203 & 0,578 & 0,571 & 0,683 & 0,867 & 0,223 & 0,564 \\
\hline X24 & 0,462 & 0,272 & 0,624 & 0,541 & 0,622 & 0,877 & 0,275 & 0,604 \\
\hline X25 & 0,145 & $-0,050$ & 0,162 & 0,188 & 0,224 & 0,231 & 1,000 & 0,239 \\
\hline X26 & 0,714 & 0,197 & 0,795 & 0,709 & 0,657 & 0,703 & 0,239 & 1,000 \\
\hline
\end{tabular}

Keterangan: $*$ variabel tidak valid

Berdasarkan Tabel 4 diatas $\mathrm{x} 4, \mathrm{x} 5, \mathrm{x} 7, \mathrm{x} 11, \mathrm{x} 14, \mathrm{x} 17$ dinyatakan tidak valid karena nilai pada indikatornya lebih rendah dari indikator lain sehingga harus dihilangkan agar semua indikator memenuhi syarat untuk dijadikan alat ukur. Selanjutnya yaitu uji discriminant validity dengan melihat nilai AVE 
Tabel 5 Nilai AVE (Average Variance Extracted)

\begin{tabular}{lc}
\hline \multicolumn{1}{c}{ Kriteria } & Average Variance Extracted (AVE) \\
\hline Daya tarik & 0,521 \\
Akomodasi & 1,000 \\
Fasilitas dan pelayanan wisata & 0,590 \\
Aksesibilitas & 0,786 \\
Kebersihan & 0,828 \\
Keamanan dan kenyamanan & 0,726 \\
Infrastruktur lain & 1,000 \\
Kriteria keseluruhan & 1,000 \\
\hline
\end{tabular}

Pada Tabel 5 keseluruhan nilai AVE berada diatas 0,5 sehingga kriteria dinyatakan lulus uji descriminant validity.

c. Uji Reliabilitas

Uji Reliabilitas pada penelitian ini dapat dilihat pada Tabel 6.

Tabel 1 Hasil uji reliabilitas

\begin{tabular}{cc}
\hline Cronbach's Alpha & Jumlah Indikator \\
\hline 0,898 & 19 \\
\hline
\end{tabular}

Berdasarkan data pada Tabel 6 diatas dengan nilai Cronbach's Alpha yaitu 0,898 (lebih besar dari 0,6) menunjukan bahwa semua konstruk pada model yang diestimasi memenuhi uji reliabilitas.

2. Pengujian Model Struktural (Inner Model)

Dalam penelitian ini standar t-tabel yang digunakan yaitu 1,96. Jika original sample bernilai positif dan t-statistik lebih besar dari 1,96, maka hipotesis diterima artinya terdapat pengaruh signifikan terhadap kriteria desain. Jika original sample bernilai negatif dan atau t-statistik lebih kecil dari 1,96 maka hipotesis ditolak yang artinya tidak terdapat pengaruh terhadap kriteria desain (Priyono dan Sunaryo, 2013). Uji hipotesis pada penelitian ini tersaji pada Tabel 6.

Tabel 6 Uji hipotesis

\begin{tabular}{|c|c|c|c|c|}
\hline & Diagram Alur & $\begin{array}{c}\text { Original } \\
\text { Sample }(O)\end{array}$ & $\begin{array}{c}\text { T Statistics } \\
(\mid \text { O/STDE V|) }\end{array}$ & Kesimpulan \\
\hline H1 & Daya Tarik =>Kriteria Keseluruhan & 0,341 & 3,897 & Diterima \\
\hline $\mathrm{H} 2$ & Akomodasi $=>$ Kriteria Keseluruhan & 0,007 & 0,154 & Ditolak \\
\hline $\mathrm{H} 3$ & $\begin{array}{l}\text { Fasilitas dan Pelayanan Wisata }=> \\
\text { Kriteria Keseluruhan }\end{array}$ & 0,296 & 2,511 & Diterima \\
\hline $\mathrm{H} 4$ & $\begin{array}{l}\text { Aksesibilitas } \\
=>\text { Kriteria Keseluruhan }\end{array}$ & 0,134 & 1,489 & Ditolak \\
\hline H5 & $\begin{array}{l}\text { Kebersihan } \\
=>\text { Kriteria Keseluruhan }\end{array}$ & 0,169 & 1,672 & Ditolak \\
\hline H6 & $\begin{array}{l}\text { Keamanan dan Kenyamanan } \\
\Rightarrow>\text { Kriteria Keseluruhan }\end{array}$ & 0,089 & 0,739 & Ditolak \\
\hline $\mathrm{H} 7$ & $\begin{array}{l}\text { Infrastruktur Lain } \Rightarrow \text { Kriteria } \\
\text { Keseluruhan }\end{array}$ & 0,055 & 1,148 & Ditolak \\
\hline
\end{tabular}


Berdasarkan hasil di atas maka kriteria daya tarik, fasilitas dan pelayanan wisata berpengaruh signifikan terhadap kriteria desain pengembangan objek wisata Waduk Sempor. Sedangkan kriteria akomodasi, aksesibilitas, kebersihan, keamanan dan kenyamanan serta infrastruktur lain berpengaruh namun tidak signifikan terhadap kriteria desain.

Uji inner model selanjutnya yaitu melihat nilai $R$-square seperti terlihat pada Tabel 7 .

Tabel 7. Nilai $R$-Square

\begin{tabular}{lc}
\hline & Nilai $\boldsymbol{R}$-Square \\
\hline Kriteria Keseluruhan & 0,765 \\
\hline
\end{tabular}

Nilai R-square $\left(R^{2}\right)$ yang terdapat pada Tabel 7 memiliki nilai sebesar 0,765 yang berarti

bahwa variabel daya tarik, akomodasi, fasilitas dan pelayanan wisata, aksesibilitas, kebersihan, keamanan dan keselamatan serta infrastruktur lain mampu menjelaskan 76,50\% dari kriteria desain pengembangan objek wisata Waduk Sempor dan sisanya sebesar 23,50 \% dipengaruhi oleh faktor-faktor lain yang tidak termasuk dalam model penelitian.

\section{SIMPULAN}

Kriteria yang berpengaruh signifikan sebagai kriteria desain pengembangan adalah daya tarik dan fasilitas pelayanan wisata, sementara kriteria yang lain berpengaruh tidak signifikan. Kriteria desain pengembangan objek wisata Waduk Sempor 76,50\% dipengaruhi oleh beberapa faktor dengan strukturisasi sebagai berikut: daya tarik (wahana main anak, spot foto, atraksi budaya lokal, festival); fasilitas dan pelayanan wisata (musholla, merchandise shop, galeri Waduk Sempor, fasilitas pelayanan kesehatan, papan informasi, papan penunjuk arah); kebersihan (papan perintah membuang sampah pada tempatnya, toilet); aksesibilitas (pencahayaan jalan, area parkir yang luas); infrastruktur lain (wastafel umum); keamanan dan keselamatan keamanan (area parkir, penjelasan tentang keselamatan, papan peringatan); akomodasi (homestay). Sedangkan 23,50\% dipengaruhi oleh faktor-faktor lain yang tidak termasuk dalam model penelitian.

\section{DAFTAR PUSTAKA}

Dewi, L. T., \& K, C. D. (2015). Analisis Prioritas Perbaikan Sistem Kerja Industri Rumah Tangga dengan metode WISH. Jurnal TRekayasa Sistem Industri, 4(1).

Hartomo, Setiawan, N., \& Kurniawan, I. (2014), Criteria Design Analysis for Develping Turism Park By Using Ergonomics Participatory Appoarch, Articles of Bali International Seminar On Science and Techlonogy (BISSTECH) II 2014.

Hawaniar, M., \& Suprihardjo, R. (2013). Kriteria Pengembangan Desa Slopeng sebagai Desa Wisata di Kabupaten Sumenep Surabaya. Jurnal Teknik Pomits, 2(3).

Pengelola Waduk Sempor, (2016), Wawancara Pengelola Objek Wisata Waduk Sempor, Kebumen.

Priyono, S., \& Sunaryo, S. (2013). Pemodelan Penggunaan Nyata Aplikasi Website E-Learning Oleh Dosen di UA menggunakan metode Partial Least Squares Structural Equation Modeling (PLS-SEM). Prosiding Seminar Nasional Manajemen Teknologi XVIII, Surabaya.

Sukapto, P. (2011). Penerapan Model Participatory Ergonomics Dalam Upaya Penurunan Kecelakaan Kerja, Penghematan Biaya, Kenaikan Produktvitas, Penurunan Kehilangan Material dan Pebaikan Lingkungan Kerja (Studi Kasus di Industri Mnufaktur di Bandung, Jawa Barat). Prosiding Seminar Nasional Manajemen Teknologi XIII.

Unga, K. L. O. (2011). Strategi Pengembangan Kawasan Wisata Kepulauan Banda. Tesis, Makassar : Program Studi Perencanaan Pengembangan Wilayah, Program Pascasarjana Universitas Hasanuddin. 
Widananto, H., \& Purnomo, H. (2013). Rancangan Mesin Pengupas Sabut Kelapa Berbasis Ergonomi Partisipatori. Seminar Nasional IENACO. 